\title{
The Effects of the Economic Crisis on Active Citizenship among Young People in Spain and what we can do about it through civic education in universities
}

\author{
Concepción Naval and Elena Arbués \\ University of Navarra
}

\section{Suggested Citation}

Naval, C. and Arbués, E. (2016). The effects of the economic crisis on active citizenship among young people in Spain and what we can do about it through civic education in universities, Citizenship Teaching \& Learning, 11 (3), 305-314, doi: 10.1386/ctl.11.3.305_1

\begin{abstract}
The recent economic crisis has had a particularly serious consequence for young people, who have suffered from a delayed transition into adulthood as a result of unemployment and job insecurity and delayed independent living. This has been particularly the case for Spain and there is a concern that these experiences of unemployment may lead to social exclusion and isolation. This article argues that learning social and civic skills may well allow young people to maintain their social connectedness and self-worth by enabling them to make connections with their local community. One institution that could offer these learning opportunities, we argue, is the university. In this article we identify the possibilities and limitations for Spanish universities to promote social and civic learning. We conclude by evaluating the support that higher education can offer young people in the context of the crisis and continued austerity.
\end{abstract}

KEYWORDS economic crisis; active citizenship; civic education; social and civic competence; higher education; employability

\section{INTRODUCTION}

Among the major challenges that a young person face in their transition to adult life are the process of entering the labour market and gaining economic and residential independence from their family. In Spain, this transition to adult life has been effected 
by the economic crisis. This crisis began with the crash of the housing bubble in 2008 and then severally worsened in 2010 because of the challenges of repaying national government debt (Bosco and Verney 2012). According to the Eurostat data, in 2014 the average youth unemployment rate in Europe was just above 20 per cent. In the same year in Spain it stood at just above 50 per cent, the highest rate of all the EU countries ${ }^{1}$. This article will explore the extent that Spanish universities can support youth through the economic crisis by facilitating the learning of civic and social competences. It will go on to argue that when there are no jobs available, teaching skills that enable young people to build relationships with their community can provide a source of resilience.

We begin this article by reviewing the situation of the realities of the lives of youth in Spain focusing on the five areas: first, the rise in age of independent living; second, unemployment and job insecurity; third, protracted years of education, fourth, emigration; and fifth, recent changes in civic behaviour. Then, we move on to argue how education and, more specifically, the development of social and citizenship skills can help young people promote participation and social competences, which we argue will provide them with the strategies and skills to tackle some of the consequences of the crisis (Naval et al., 2011; Laker et al., 2014). We will then address the university as an institution and identify the extent to which they can offer relevant opportunities for learning civic competences to improve and transform society (Martínez and Esteban 2005; Kronman 2007; Rochford 2008).

\section{THE EFFECTS OF THE CRISIS ON YOUNG SPANIARDS}

Spain has undergone and continues to undergo, perhaps more radically than in other countries in the Western world, the grave consequences of the economic crisis. The economic and social collapse Spain has been strongly felt in all aspects of social and political life. The latest Informe Juventud en España (Report on Spanish Youth), published by the Instituto de la Juventud (Injuve 2012), identifies the following consequences for young people of the years of crisis: first, the rise in the age at which young people become independent and the resulting economic dependence on their parents; second, the increase in unemployment and job insecurity; third, the increase in the years of schooling and the reduction of the dropout rate from school; and fourth, the

\footnotetext{
${ }^{1} \mathrm{Cfr}$. http://ec.europa.eu/eurostat/data/database
} 
growth of migration. We shall investigate these issues below and their effects on political engagement.

\section{Rise in the age of independence}

In the second half of the twentieth-century, Spain has been characterized as having high levels of family dependence among young people compared with other European countries. In fact, in comparative terms, Spain is the European country in which most young people continue living with their parents, at just over $60 \%$, followed by Portugal and Italy. In contrast, Finland, Norway and Sweden are the countries with the lowest number of young people living in the family home (Moreno et al. 2012). In the year 1999, about 70\% of the young people between 16 and 34 years were living their parents. Although the degree of dependence decreased gradually until 2007 at just under $60 \%$, from the moment of the crisis these figures began to rise rapidly (Moreno et al. 2012). We argue that this could we be a result of the high level of unemployment among young people and the lack of job security for those in work.

\section{Unemployment and precarious labour conditions}

Unemployment, which is quite a common phenomenon in the south of Europe and in Ireland, has increased considerably among young people in Spain since the economic crisis. In 2015, according to the Survey on Active Population (EPA, first quarter 2015), carried out by the National Institute for Employment (INEM), 51\% of young people under 25 who were looking for employment were unemployed, among the age group 25-29 years $36 \%$ of the active population were unemployed and among the age group 30-34 years 28\% were unemployed. We argue that this situation produces a greater feeling of vulnerability among young people. It may well also relate to why young people are staying at home longer and staying in education for longer - a point that we shall address below.

\section{Increase in the years of schooling and the reduction of the dropout rate}

In Spain, the increase in the percentage of young people completing secondary school and going on into higher education can in part be attributed to the economic crisis for two reasons: first, the EU funding for projects aimed at addressing early school leavers then became available; and second, the very fact that there were fewer 
jobs available for those without qualifications encouraged young people to stay on longer education. Since the early 1990s, there has been about a 10\% rise in young people completing secondary education to just over 60\% in 2011 (OECD, 2012). However, it must be noted that Spain is still among the countries with the lowest number of young people finishing secondary education compared with other countries such as Finland or Sweden that both have a about a $85 \%$ completion rates. In terms of higher education in the academic year 2012-2013 in Spain, there were 1,046,570 degree students and 111,087 master's students. The net rate of university attendance of 18 to 24-year-olds continues to grow and stands in the academic year 2013-2014 at just under 30\% (in the academic year 2008-09 it was closer to 20\%) ${ }^{2}$. It is interesting to note that Spain university graduates have been less affected by the crisis than have their less qualified compatriots. According to the Spanish National Institute for Employment (INE), there are higher rates of employment among those with greater training; they find employment more quickly; they have greater work security and higher salaries. In Spain in 2012, 49\% of the offers of employment were for graduates. Nevertheless, it should be taken into account that $22.6 \%$ of the employed university graduates hold a position for which they are overqualified (INE, 2012) $)^{3}$.

\section{The growth of emigration}

Up to the end of 2010, Spain had been a country with more immigration than emigration. The number of registered foreigners or holders of valid residency cards was just under five million on the 31 December 2014. During 2014 the number of foreigners dropped by about 20,000 with those leaving mostly from Latin America. Nevertheless at the same time there were arrivals from inside the EU, mainly from Romania, Italy and the United Kingdom ${ }^{4}$.

The youth population of Spain was traditionally characterised by very little geographic mobility. However, in 2014 almost 80,000 Spanish nationals emigrated,

\footnotetext{
${ }^{2}$ Ministerio de Educación Cultura y Deporte. Datos básicos del sistema universitario español. Curso 2013-2014. Cfr. http://www.mecd.gob.es/dms/mecd/educacion-mecd/areas-educacion/universidades/ estadisticas-informes/datos-cifras/DATOS_CIFRAS_13_14.pd

${ }^{3} \mathrm{Cfr}$. http://www.ine.es/jaxi/menu.do?type=pcaxis\&path=/t13/p405\&file=inebase

${ }^{4}$ Cfr. Gobierno de España. Ministerio de Empleo y Seguridad Social. Secretaría General de inmigración y emigración. http://extranjeros.empleo.gob.es/es/Estadisticas/operaciones/con-certificado/index.html
} 
which is almost double the number from 2010 (INE 2014) ${ }^{5}$. The age group from which the most number of people left the country was between 25 and 29. This leads us to believe that many of these young people had finished their studies, and were facing the challenges of finding employment in Spain and found more opportunities for work in other countries. The crisis had activated the migratory process among young people to other countries with greater labour and economic opportunities. The United Kingdom, France, Germany and the United States are the main destinations for Spanish migrants.

\section{Impact on youth attitudes and political engagement}

Various authors have warned of the consequences and dangers to which young people in the south of Europe are exposed in this crisis situation. These include the following: insecurity and social exclusion (Williamson, 2014); lack of satisfaction with democracy (Campos \& Martín, 2015); a feeling of dissatisfaction with the EU (Simsa, 2015); the growth of far-right politics as a way of punishing the political system for its tough austerity policies (Koronaiou et al., 2015); or receptiveness to radical and populist political agendas (Pilkington \& Pollock, 2015).

In the Injuve report (Injuve, 2012) the authors argue that there have been certain effects of the crisis on the attitudes of Spanish youth:

- Greater priority placed on the individual and their private milieu.

- Greater awareness of the everyday realities of the current economic condition and social inequalities.

- Increased disinterested in formal politics.

- Almost half have participated in the last 12 months in authorised demonstration.

- Although the majority trusts the democratic system, there has been a rise in those opinions that justify other types of political systems.

Although the association between the crisis and these changes in attitudes cannot easily be proved, the associations suggested by these authors provide some cause for concern.

Nevertheless, it is important to add that in Spain the economic and social situation has not lead to a drop in solidarity or the rise of the extreme right, as has occurred in other European countries such as Greece. As Simsa states, “contrary to other EU-

\footnotetext{
${ }^{5} \mathrm{Cfr}$. http://www.ine.es/jaxi/menu.do?type=pcaxis\&path=\%2Ft20\%2Fp277\&file=inebase\&L $=0$
} 
countries the disaffection and rejection of traditional institutions has yet not lead to right wing populism or political inactivity of young people but to a strengthening of civil society engagement and the formation of new parties” (2015:3). For example, Spanish youth have increasingly been engaged in social movements. In 2012, there were over 40,000 protests. The rise of the $15 \mathrm{M}$ movement (a reference to the public demonstrations on 15 May 2011, first in Madrid and later in other capital cities like London and New York) was an example of the high level of engagement of young people in social movements (Jover et al. 2014). These protests were a symbol of citizen outrage against the government and international institutions, pressure towards the implementation of austerity policies, and an expression of meta-political frustration reflecting the degree of dissatisfaction with the functioning of democracy (Flesher Fominaya 2015; Campos \& Martín, 2015). The movements were by their nature forms of participatory democracy and bottom-up citizens initiatives such as those designed to route-out corruption within politics (Flesher Fominaya 2015). In Spain these protest movements have metamorphosed into political parties -for example, Podemos was built from the 15M movement.

It can be argued that young people have to a certain extent through social movements and participatory activities been trying to develop solutions for themselves. Nevertheless, this does not negate the responsibility of education institutions to support young people through the continued crisis with civic knowledge and participatory opportunities. This will be the focus for the second section of this article.

\section{SOCIO-EDUCATIONAL CHALLENGES. WHAT CAN WE DO ABOUT THEM?}

There are many potential responses on different policy topics and at different levels of governance to assist young people within the context of the economic crisis, including social policies on housing, vocational training and employment activation measures. Nevertheless, a different approach would be to support the learning of young people's social and civic skills that could help young people maintain their place within society when faced with unemployment in a situation where there is a very limited chance of finding other work. These skills would allow young people to maintain social connectedness and self-worth during periods of unemployment through building human 
relationships and connections with their local community (Naval et al., 2011; Laker et al., 2014).

Clearly these skills would need to be developed across compulsory education. Nevertheless, one institution that could also offer these learning opportunities, we argue, is the university. However, we do realise that universities can only provide part of the solution as not all young people in Spain attend university but with ever greater numbers of students applying including those from non-traditional routes (Zabalza 2002), universities could play a role as part of the support mechanism for youth.

Recent Spanish laws on higher education have to a certain extent reflected this need to support youth on civic and social participation. The 2007 Organic Law on Universities (LOU or Spanish Universities Act) identifies the need for greater involvement of universities in the enhancement of the training of their graduates so that they will be capable of adapting to both social demands and the demands of the scientific and technological system. The 2007 Organic Law establishes student participation as one of the principles of university policies through the Student Statute and the creation of a University Student Council. The Statue establishes the mechanisms to increase the involvement of students in university life, recognises their rights and places a value on their participation in the different governing bodies (Royal Decree 1791/2010, 30 December). In addition, this law introduces the possibility for students to obtain academic recognition for their participation in cultural, sporting, student representation, solidarity and cooperation activities (Art. 46.i). Implementing these laws would facilitate the promotion of social participation in higher education. However, the implementation of these laws has been limited, and Spanish Universities are still far from fulfilling them.

Among the aims of the university, apart from a proper technical and professional preparation, are the development of mature, reflexive, critical individuals and an awakening of interest in civic issues among its students (Llano 2003). This implies two aspects: the first, critical and the second, participatory. Thus, the university cannot resign itself to merely transmitting instrumental knowledge, but most also see itself as a collaborator in the education of future professionals and future citizens.

Building from extensive research on civic competence (Hoskins et al 2015, 2011), the aims of civic education at universities are two types of skills:

- Intellectual skills, which facilitate students' ability to think critically, by helping them be reflexive citizens who are capable of openly and constructively criticizing the 
status quo, and the development of individual personal leadership skills, integrity and the capacity for decision-making.

- Participative skills, which help the students to increase their civic commitment and to exercise active citizenship responsibly including communication skills, negotiation skills, and ability to solve problems and resolve conflicts, initiative, and teamwork.

These skills may be developed in higher education within the different subjects in a theoretical-practical way.

A potential methodology to use in the university context in Spain for teaching these skills is Service-Learning, which has been considered successful in the United States and other English-speaking countries. This training method combines the processes of learning and services to the community in one. In a well-designed service learning project the students are involved in the real needs of their community and helping the community improve itself (Martínez, 2008; Warren, 2012; Batlle, 2013). These programs are associated, in their definition, application and development, with the patterns of cognitive and social improvement for university students and offer potential for innovation in Spanish higher education (Ugarte y Naval, 2010). This methodology aims to strengthen a perspective on university student academic learning where the cognitive, affective and social dimensions are linked in order to optimise personal growth and advance in the achievement of professional competences. Within the context of present-day university learning, we can clearly see a concern for the linking of theoretical and practical learning. In this sense, the Service-Learning methodology may be useful in order to base student learning on real experience, to connect with their motivations and to promote students committed participation (Naval et al., 2011).

For the moment, the presence of Service-Learning in universities in Spain has been developing slowly and in quite an isolated way. Only in a few working groups involved in teacher training and innovation have there been proposals for such courses, but there is no structured connection with governing bodies at any academic level. The Civicus Project, promoted by the Vytautas Magnus University (Lithuania) and funded by the EU (Leonardo da Vinci Programme), has been quite an important milestone in developing service learning in Spain. The research project endeavoured to explore the means and strategies for cooperation between universities, the civil service and community organizations (Martínez-Odria, 2007). 


\section{CONCLUSION}

In this article, we have endeavoured to explore the realities of the lives of young people in Spain and identify the major challenges that they face. In a second step we have identified potential avenues that universities in Spain can offer to support them through learning opportunities that foster social and civic competences. In this context, higher education was identified as one place where this support can occur, and recent Spanish law on higher education would potentially support this learning and service learning is argued as one possible method to support this learning. In addition, the development of social and emotional skills such as leadership and teamwork in higher education requires teachers to explain to the students that the stimulation to help other is at the heart of the motivation towards personal improvement. Frequently, we believe this will move the individual to participate, to be involved in social and civic issues, as a means to find, in as far as possible, solutions to improving the current social and economic problems in Spain. Thus, we argue that the development of intellectual proficiencies does not merely facilitate reflection and analysis, but also increases social participation. The objective of developing intellectual and participative skills can be seen in the consolidation habits, which are the practical and operative proof of personal and social values. Educating professionals and critical and participative citizens in the university area implies enabling students to form attitudes such as respect, solidarity, tolerance, comprehension, civic courage -tenacity or fortitude- in their fidelity to their own convictions (Medina 2002), interest in political and social problems, political confidence and efficacy, and loyalty (Naval 2000). These skills are, we would argue, essential for quality professional achievement and are the basis for critical and reflective thinking, and also for that civic commitment which contributes to the common good.

\section{REFERENCES}

Batlle, R. (2013), 60 buenas prácticas de aprendizaje servicio/60 good service learning practices, San Sebastian: Fundación zerbikas.

Bosco, A. and Verney, S. (2012), Electoral Epidemic: the political cost of economic crisis in Southern Europe, 2010-11, South European Society and Politics, 17(2), 129-154.

Campos, M. P. \& Martín, A. (2015), Youth voice(s) in EU countries and social movements in southern Europe, Transfer, 19(3), 345-363. 
Flesher Fominaya, C. (2015), 'Debunking Spontaneity: Spain's 15-M/Indignados as Autonomous Movement', Journal of Social, Cultural and Political Protest, 14: 2, pp. 142-163.

Hoskins, B., Saisana, M. \& Villalba, C. M. H. (2015) Civic Competence of Youth in Europe: Measuring Cross National Variation through the Creation of a Composite Indicator. Social Indicator Research, 123, 2, 431-457. http://link.springer.com/article/10.1007/s11205-014-0746-z\#. Accesed 31 July 2016.

Hoskins, B., Barber, C., Van Nijlen, D., and Villalba, E. (2011) Comparing civic competence among European youth: composite and domain-specific indicators using IEA civic education study data. Comparative Education Review, 55, (1), 82110.

Injuve (2012), Informe juventud en España 2012/Report on Spanish youth 2012. Madrid: Instituto de la Juventud.

INE (2012), 'Web of Statistics National Institute', http://www.ine.es/jaxi/menu.do? type=pcaxis\&path=/t13/p405\&file=inebase. Accessed 2 April 2015.

— (2014), 'Web of Statistics National Institute: Migration Statistics', http://www.ine.es/jaxi/menu.do?type=pcaxis\&path=\%2Ft20\%2Fp277\&file=ineba se\&L=0. Accessed 2 April 2015.

Jover, G., Belando-Montoro, M. and Guío, Y. (2014), 'The political response of Spanish youth to the socio-economic crisis: some implications for citizenship education', Journal of Social Science Education 13, 3, pp. 4-12.

Koronaiou, A., Lagos, E., Sakellariou, A., Kymionis S. \& Chiotaki-Poulou, I. (2015), Golden Dawn, austerity and young people:the rise of fascist extremism among Youngpeople in contemporary Greek society, The Sociological Review, 63:S2, 231-249.

Kronman, A. T. (2007), Education's end: Why our colleges and universities have given up on the meaning of life, New Haven, CT: Yale University Press.

Laker, J., Naval, C. \& Mrnjaus, K. (2014), 'The Folly of Employability. The case for a citizen-driven market economy', Annales. Series Historia et Sociologia, 24 2014, 3, pp. 397-406.

Ley Orgánica 4/2007, 12 de abril, por la que se modifica la Ley Orgánica 6/2001, de Universidades, de 21 diciembre. 
Llano, A. (2003), Repensar la universidad: la universidad ante lo nuevo/Rethinking university: University versus the new, Madrid: Ediciones Internacionales Universitarias.

Martínez, M. (2008) (ed.), Aprendizaje servicio y responsabilidad social de las universidades/Service learning and social responsibility of universities, Barcelona: Octaedro-ICE.

Martínez, M. and Esteban, F. (2005), 'Una propuesta de formación cívica para el EEES'/A proposar for civic education to EEES, Revista Española de Pedagogía, 230, pp. 63-83.

Martínez-Odria, A. (2007), Service-learning o aprendizaje-servicio. La apertura de la escuela a la comunidad local como propuesta de educación para la ciudadanía/Service-learning or aprendizaje-sercicio. The opening of the school to the local community as a proposed citizenship education, Bordón, 59, 4, 627-639.

Medina, R. (2002), La formación en los valores de los derechos humanos. Fundamento de la convivencia y la paz/Training in human rights values. Foundation of coexistence and peace, Madrid: Real Academia de Doctores.

Moreno Mínguez, A; López, A. y Sánchez, S. (2012), La transición de los jóvenes a la vida adulta. Crisis económica y emancipación tardía/The transition from youth to adulthood: economic crisis and late emancipation, Barcelona: Fundación La Caixa.

Naval, C. (2000), 'Educación y derechos humanos'/Education and human rigths, Humana Iura, 10, pp. 43-59.

Naval, C., García, R., Puig, J. M. y Santos, M. A. (2011), 'La formación ético-cívica y el compromiso social de los estudiantes universitarios'/Ethical and Civic Education and the Social Commintment of University Students, Encounters on Education, 12, pp. 77-91.

OECD (2012), Equity and Quality in Education: Supporting Disadvantaged Students and School, OECD Publishing. http://dx.doi.org/10.1787/9789264130852-en. Accessed 31 July 2016.

Pilkington, H. \& Pollock, G. (2015), 'Politics are bollocks': youth, politics and activism in contemporary Europe, The Sociological Review, 63:S2, 1-35

Rochford, F. (2008), 'The contested product of a university education', Journal of Higher Education Policy and Management, 30, 1, pp. 41-52. 
Royal Decree 1791/2010, 30 December, por el que se aprueba el estatuto del estudiante universitario (BOE $\mathrm{n}^{\circ}$ 318, de 31 de diciembre de 2010).

Simsa, R. (2015), The Social Situation in Spain and the Spanish Protest Movement: The EU Needs Dialogue and Immediate Corrective Action, Wien. ÖGfE Policy Brief, 2.

Ugarte, C. and Naval, C. (2010), 'Desarrollo de competencias profesionales en la educación superior'/Developing Professional Competences in Higher Education, Revista Electrónica de Investigación Educativa (special issue), 12(1), 1-14.

Warren, J. L. (2012), Does Service-Learning Increase Student Learning?: A MetaAnalysis, Michigan Journal of Community Service Learning, Spring 2012, pp. 5661.

Williamson, H. (2014), Radicalization to retreat: responses of the young to austerity in Europe, International Journal of Adolescence and Youth, Vol. 19, No. S1, pp. 518, http://dx.doi.org/10.1080/02673843.2013.812041. Accessed 31 July 2016.

Zabalza, M. A. (2002), La enseñanza universitaria. El escenario y sus protagonistas/ University education: The stage and its protagonists, Madrid: Narcea.

\section{CONTRIBUTOR DETAILS}

C. Naval, PhD in Education, University of Navarra (1989). She was awarded a scholarship in the pre-doctoral program of the Spanish Ministry of Education, and a postdoctoral fellowship by the Fulbright Commission. Professor of Educational Theory, University of Navarra, since 1993. She directed the Department of Education (19962001), and was Vice President (2001-2012). Dean of the School of Education and Psychology since December 2013. Visiting Scholar at Harvard University, University of Notre Dame, International Office of Education of UNESCO, St. Edmund's College, Cambridge University, and Boston University. Visiting Professor at Universidad Panamericana (Mexico). Fellow of Salzburg Seminar (2003); Visiting Fellow and Oliver Smithies Lecturer, Balliol College, University of Oxford (2012-13), and Academic Visitor, Columbia University (2013). Editor of the Journal Estudios sobre Educación. Co-author of Civic Pedagogies in Higher Education (2014), Citizenship, Democracy and Higher Education in Europe, Canada and the USA (2014).

Contact: Universidad de Navarra, Facultad de Educación y Psicología, Campus Universitario 31009, Pamplona, Navarra, Spain.

E-mail: cnaval@unav.es 
E. Arbués is a qualified primary school teacher and holds a Master's degree in Marriage and Family. She has developed her professional activities in various schools as primary school teacher, and as a family and educational counsellor. $\mathrm{PhD}$ in Education, University of Navarra (2011). She is currently Adjunct Professor of Didactics of Experimental Sciences at the University of Navarra. Visiting Scholar at University of Oxford (2012). She is involved in various projects and her research focuses primarily on civic education and the promotion of social participation.

Contact: Universidad de Navarra, Facultad de Educación y Psicología, Campus Universitario, 31009, Pamplona, Navarra, Spain.

E-mail: earbues@unav.es 